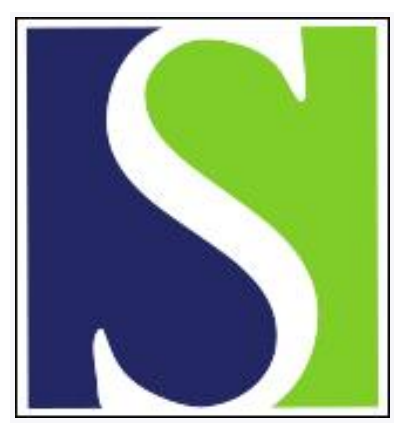

Scand J Work Environ Health 1983;9(2):181-188

https://doi.org/10.5271/sjweh.2440

Issue date: Apr 1983

Inhalation studies of diesel exhaust and coal dust in rats.

by Green FH, Boyd RL, Danner-Rabovsky J, Fisher MJ, Moorman WJ, Ong TM, Tucker J, Vallyathan V, Whong WZ, Zoldak J, et al.

This article in PubMed: www.ncbi.nlm.nih.gov/pubmed/6196842

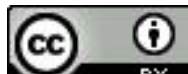




\title{
Inhalation studies of diesel exhaust and coal dust in rats
}

\author{
by Francis HY Green, MD, ' R Lee Boyd, PhD, ${ }^{2}$ Jean Danner-Rabovsky, PhD,' \\ Martin J Fisher, PhD, ${ }^{2}$ William J Moorman, MS, ${ }^{1}$ Tong-Man Ong, PhD, ${ }^{1}$ \\ James Tucker, BS, ${ }^{1}$ Val Vallyathan, PhD, ' When-Zong Whong, PhD, ${ }^{1}$ \\ John Zoldak, BS, ${ }^{3}$ Trent Lewis, $\mathrm{PhD}^{1}$
}

\begin{abstract}
GREEN FHY, BOYD RL, DANNER-RABOVSKY J, FISHER MJ, MOORMAN WJ, ONG T-M, TUCKER J, VALLYATHAN V, WHONG W-Z, ZOLDAK J, LEWIS T. Inhalation studies of diesel exhaust and coal dust in rats. Scand $j$ work environ health 9 (1983) 181-188. The preliminary 12-month data of an ongoing two-year chronic inhalation study into the effects of diesel exhaust and coal dust on rats are reported. The study design consists of four exposure regimens: coal dust, diesel exhaust, coal dust plus diesel exhaust, and filtered air (control). Total respirable particulate is being maintained at $2 \mathrm{mg} / \mathrm{m}^{3}$ in all exposure groups. Animals are being serially sacrificed and subjected to immunologic, biochemical, physiological, microbiological, and pathological evaluations. Extracts of diesel emissions showed marked mutagenic activities in the Ames Salmonella his reversion assay. Mutagenic compounds were not however found in the urine of the exposed animals, nor were sister chromatid exchanges detected in peripheral lymphocytes. No changes were observed in cytochrome P450 enzyme activity in lung microsomes of exposed rats. Physiological tests showed no evidence of pulmonary function impairment in any group. Light microscopic examination of the lungs showed dust deposition with the formation of macules in all exposed groups. The preliminary results revealed few pathological effects of significance and no evidence of synergism between diesel exhaust and coal dust.
\end{abstract}

Key terms: morphometry, mutagens, pneumoconiosis, pulmonary function, toxicology, xenobiotic metabolism.

The use of disel powered units in underground coal mines has been very limited in the United States. As of June 1976 there were approximately 180 dieselpowered units in 25 coal mines in this country. Diesel-powered equipment has however been used more extensively in European underground coal mines and in metal and nonmetal mines in the United States. Diesel equipment in underground mines offers several theoretical advantages over conventional electrical powered equipment, notably greater economy and safety, and for these reasons there is a

1 National Institute for Occupational Safety and Health, Morgantown, West Virginia, and Cincinnati, Ohio, United States.

2 University of Florida, Gainesville, Florida, United States.

3 West Virginia University, Morgantown, West Virginia, United States.

Reprint requests to: Dr FHY Green, NIOSH Pathology Section, 944 Chestnut Ridge Road, Morgantown, WV 26505, USA. trend toward an increasing use of diesels in coal mines.

Although there is substantial knowledge concerning the toxic effects of coal mine dust and the constituent pollutants in diesel exhaust, very little is known about the effects of diesel emissions in the underground mining environment or of the possible interactions between mine dusts and these emissions. Because some of the theoretical end points of these interactions are potentially important, for example, emphysema and lung cancer, the National Institute for Occupational Safety and Health (NIOSH) has inititated a series of epidemiologic and laboratory-based studies into the problem.

Cross-sectional epidemiologic studies comparing ventilatory functions and the radiographic category of pneumoconiosis between miners in dieselized and nondieselized coal mines indicate few differences between the groups $(1,19)$, although 
in one of these studies a possible effect of diesel emissions on small airway function was observed (19). Clearly information concerning possible carcinogenic effects of these combined exposures cannot be generated by cross-sectional studies.

Prospective longitudinal studies have been initiated; however it will be many years before answers to these questions can be generated by this approach.

More immediate information on the possible adverse health effects can be provided by in vivo and in vitro laboratory studies. Only one investigation to date has been published concerning the combined effects of diesel emissions and coal dust in animals (12). With dose levels higher than in the present study, lesions of pneumoconiosis developed in all the exposed animals. There was no evidence of a synergistic effect between the diesel emissions and coal dust. Also no excess of neoplasms was observed in either the diesel-exposed or diesel-plus-coal-dust-exposed animals, despite the presence of carcinogenic hydrocarbons in the diesel emissions.

The experimental studies described were initiated in 1980. The present report is a preliminary analysis of the first 12 months of exposure.

\section{Methods and results}

Inhalation exposure facilities at the Environmental Protection Agency's laboratory at Center Hill, Cincinnati, were acquired for this study. The study design consisted of four exposure regimens: coal dust, diesel exhaust, coal dust plus diesel exhaust, and filtered air (control). Two animal species, Specific Pathogen Free (SPF) Fischer 344 weanling rats and Cynomolgus monkeys (Macaca fasicularis), were used. The experimental protocol for the monkeys will not be discussed further in the present report. The rats were immunized against Sendai virus, and serological testing was conducted against Mycoplasma pulmonis at various time points. After a two-week quarantine period the rats were placed in the chambers for the duration of the experiment. They received food and water ad libitum. They were maintained at a temperature of $21-22^{\circ} \mathrm{C}$ and a relative humidity of $50-$
$55 \%$. Exposures were for $7 \mathrm{~h} / \mathrm{d}, 5 \mathrm{~d} /$ week for up to two years. During the exposure period the chambers were darkened in order to simulate the rodents' active nocturnal period.

The rats were housed in duplicate sets of four exposure chambers with 144 animals per chamber. One set of exposure chambers containing equal numbers of male and female rats was left intact until termination of the exposure period at two years, at which point the animals were sacrificed. The protocol for this group conformed to the bioassay guidelines of the National Cancer Institute. Animals from the other set containing all males were serially sacrificed at $3,6,12$, and 24 months and subjected to microbiological, immunologic, biochemical, physiological, and pathological evaluations.

Exposure chambers of the design of Hinners et al (10) were used. The chambers featured tangential inlet air assemblies to provide adequate aerosol distribution. Airflow was maintained at 25 cubic feet per minute $\left(0.0118 \mathrm{~m}^{3} / \mathrm{s}\right)$ and chamber loading was minimal as reflected in the ammonia levels at less than $1-2 \mathrm{ppm}$. The overall design of the inhalation facility has been published elsewhere (9).

The diesel emissions were generated by a four-cylinder, four-cycle Caterpillar diesel engine identical to those used in some underground coal mines in the United States. The engine consumed number 2 diesel fuel containing less than $0.5 \%$ sulfur and was equipped with a water exhaust scrubber. To provide a representative diesel exhaust exposure, the engine was operated in a repetitive eightmode simulated duty cycle which varied engine load and speed. Approximately $55 \%$ of the cycle was in the idle mode.

The coal sample was obtained from the Pittsbrugh seam, 600 feet $(183 \mathrm{~m})$ below the surface, at Blacksville Number 1 Mine, West Virginia. This seam was chosen because it is the largest Eastern bituminous coal seam high enough to be exploited by diesel equipment. Large freshly cut fragments of coal were selected from the face, micronized to approximately $40 \%$ by weight respirable fraction (diameter $<7 \mu \mathrm{m}$ ), and sealed under nitrogen until generated into the exposure chambers by a Wright dust feeder. 
The total particulate levels were as follows: $5 \mathrm{mg} / \mathrm{m}^{3}$ in coal exposures, 3 $\mathrm{mg} / \mathrm{m}^{3}$ in diesel-exhaust-plus-coal exposures, and $2 \mathrm{mg} / \mathrm{m}^{3}$ in diesel exhaust exposures. Respirable particulate was maintained at $2 \mathrm{mg} / \mathrm{m}^{3}$ in all exposure groups. This level was chosen as it represents the current federal permissible limit of respirable particulate in underground coal mines. Thus animals exposed to coal dust received $2 \mathrm{mg}$ of coal dust $/ \mathrm{m}^{3}$, animals exposed to diesel exhaust received 2 $\mathrm{mg}$ of diesel particulate $/ \mathrm{m}^{3}$, and those exposed to combined coal dust and diesel exhaust received $1 \mathrm{mg}$ of coal dust $/ \mathrm{m}^{3}$ plus $1 \mathrm{mg}$ of diesel particulate $/ \mathrm{m}^{3}$. The level of diesel particulate in the latter exposure group was halved by splitting the diesel exhaust into two equal streams and passing one through a bag house filter system to remove particulate. This system left the gases intact; thus animals in the diesel exhaust alone or diesel exhaust plus coal dust groups received the same concentrations of gases.

Respirable concentrations of particulate were gravimetrically monitored daily and maintained within narrow limits (table 1). Table 1 also shows the average concentrations of the gases carbon dioxide, carbon monoxide, nitrogen monoxide, nitrogen dioxide, sulfur dioxide, and ammonia for the first 12 months of exposure. It can be seen that all the concentrations were well within permissible exposure limits for airborne contaminants in the mines.

The following biological parameters were measured: body and organ weights, biochemical and hematological profiles, B and $\mathbf{T}$ cell immune function, mutagenesis assays of exposure particulates and urine, lymphocyte sister chromatid exchanges, cytochrome P450 enzyme activity in liver and lungs, alveolar macrophage function, pulmonary function, and histopathology. No significant differences between the four groups were detected for total body weight or for the weights of the lungs, heart, liver, spleen, kidneys and testes at 12 months. Hematologic profiles at 12 months showed no significant differences in hematocrit, white cell counts, or differentials. No differences were noted in serological assays of total proteins, albumin, glucose, calcium, phosphorus, cholesterol, uric acid, creatinine, bilirubin, or the enzymes alkaline phosphatase, lactic acid dehydrogenase and aspartate aminotransferase.

\section{Mutagenesis assays}

Dichloromethane extracts of diesel particulate or coal mine dust were tested for mutagenicity in the Ames Salmonella his reversion assay (2) with and without S-9 activation (table 2). The dichloromethane extract from coal dust was not mutagenic. However, dichloromethane extract from diesel emission was mutagenic in both the TA98 and TA100 strains of Salmonella typhimurium with and without S-9 activation. A concentration of $2.63 \mathrm{mg} /$ plate caused an approximate tenfold increase in the number of revertants per plate over the background control (TA 98 with S-9 activation). There was no evidence of synergism between diesel exhaust and coal dust.

Urine from male animals exposed for three and six months was collected over a 5-d period immediately after the exposures, concentrated with an XAD-2 column, and analyzed for the presence of mutagenic compounds (21). None of the urine samples from animals exposed to coal dust, diesel emission, or coal dust plus diesel emission showed any mutagenic

Table 1. Chamber data - 12-month summary for rats.

\begin{tabular}{lccccccc}
\hline Exposure & $\begin{array}{c}\text { Carbon- } \\
\text { dioxide } \\
(\%)\end{array}$ & $\begin{array}{c}\text { Carbon } \\
\text { monoxide } \\
(\mathrm{ppm})\end{array}$ & $\begin{array}{c}\text { Nitrogen } \\
\text { monoxide } \\
(\mathrm{ppm})\end{array}$ & $\begin{array}{c}\text { Nitrogen } \\
\text { dioxide } \\
(\mathrm{ppm})\end{array}$ & $\begin{array}{c}\text { Sulfur } \\
\text { dioxide } \\
(\mathrm{ppm})\end{array}$ & $\begin{array}{c}\text { Ammonia } \\
(\mathrm{ppm})\end{array}$ & $\begin{array}{c}\text { Respirable } \\
\text { particulate } \\
\left(\mathrm{mg} / \mathrm{m}^{3}\right)\end{array}$ \\
\hline Diesel exhaust & 0.21 & 12.7 & 9.7 & 1.6 & 0.83 & 1.13 & 2.01 \\
Diesel exhaust & 0.20 & 11.1 & 8.4 & 1.3 & 0.56 & 0.54 & 2.08 \\
and coal dust & 0.09 & 2.4 & 0.08 & 0.04 & $-\overline{01}$ & 0.83 & 1.97 \\
Coal dust & 0.08 & 2.3 & 0.07 & 0.04 & 0.01 & 0.63 & - \\
Filtered air & & &
\end{tabular}


Table 2. Mutagenicity of particulates from diesel emission and/or coal dust in Salmonella typhimurium.a (DMSO = dimethyl sulfoxide)

\begin{tabular}{|c|c|c|c|c|c|}
\hline \multirow{3}{*}{$\begin{array}{l}\text { Particulate } \\
\text { sample }\end{array}$} & \multirow{3}{*}{$\begin{array}{l}\text { Amount of } \\
\text { particulate } \\
\text { (mg/plate) }\end{array}$} & \multicolumn{4}{|c|}{ Histidine independent revertant } \\
\hline & & \multicolumn{2}{|c|}{ TA98 (revertants/plate) } & \multicolumn{2}{|c|}{ TA100 (revertants/plate) } \\
\hline & & - $\$ 9$ & $+\$ 9$ & $-\$ 9$ & $+\$ 9$ \\
\hline Negative control (DMSO) & 一 & 37 & 42 & 100 & 112 \\
\hline Positive control (2AA) b & - & - & 2,114 & - & 2,450 \\
\hline Clean air & 0.0225 & 39 & 40 & 86 & 138 \\
\hline Coal dust & 5.66 & 46 & 66 & 98 & 145 \\
\hline Diesel emission & 2.63 & 284 & 445 & 738 & 676 \\
\hline Coal dust and diesel emission & 4.56 & 182 & 299 & 455 & 446 \\
\hline
\end{tabular}

a Sample was extracted with dichloromethane for $16 \mathrm{~h}$ with shaking. The extract was concentrated and dissolved in DMSO.

b $2.5 \mu \mathrm{g} \mathrm{2-aminoanthracene/plate.}$

activity. Lymphocyte sister chromatid exchanges were assessed in groups of 10 animals exposed to either air or combined diesel exhaust and coal dust for three months by a modification of the technique of Perry \& Wolff (17). The mean frequencies of the sister chromatid exchanges for the control and treated animals were 0.22 and 0.23 per chromosome, respectively. The differences were not statistically significant.

\section{Xenobiotic metabolism}

A very important enzyme system responsible for the metabolism of xenobiotics is the inducible cytochrome P450 system (6, 16). The complex is also responsible for the biological activities of many occupational/environmental pollutants which require prior metabolism before becoming active $(6,8)$. This enzyme complex is known to be operative in rat lung and can be induced by foreign substances (18). To investigate the effect of coal dust and/or diesel exhaust on the cytochrome P450 system, enzyme activities associated with the complex were measured in the microsomal fraction of lungs and liver from rats exposed for three months $(5,7$, 15). No changes in the level of NADPHcytochrome c reductase, ${ }^{4}$ benzo(a)pyrene hydroxylase, or 7-ethoxycoumarin deethylase activities were observed in the liver or lung microsomes of these animals. Additional experiments are in progress to

$4 \mathrm{NADPH}=$ reduced nicotinamide adenine dinucleotide phosphate. analyze the activities in animals exposed for longer periods of time.

\section{Pulmonary function and morphometry}

Pulmonary function was measured by the method of Boyd et al (3) in groups of 10 rats exposed for 12 months. The following variables were defined: body weight, functional residual capacity, inspiratory and total airway resistance, inspiratory and total airway specific conductance, phase difference between airflow rate and mean alveolar pressure, frequency of breathing, tidal volume, and minute ventilation. The data for each variable were compared between the treatment groups by an analysis of variance and a $2 \times 2$ factorial analysis of variance. A probability level of $\alpha 0.05$ was set for significance. No significant differences were detected between the treatment groups for any of the variables measured.

After pulmonary function testing, the lungs were excised and fixed with Karnovky's fixative by intratracheal perfusion at a pressure of $20 \mathrm{~cm} \mathrm{H} \mathrm{H}_{2} \mathrm{O}$ for $24 \mathrm{~h}$ and then stored in Karnovsky's fixative. The extrapulmonary tissue was removed from each respiratory system, and the specific volume was measured by water displacement. The lungs were sectioned into six pieces: upper left, middle left, lower left, upper right, middle right, and lower right. Each piece was trimmed to $5 \times 5 \times 10$ $\mathrm{mm}$, dehydrated, and embedded in glycomethacrylate. Sections were cut at $2 \mathrm{~mm}$ and stained with toluidine blue; morphometric analysis of the tissue sections was 
performed with a semiautomated point counting system modified after the method of Weibel (20). The following parameters were assessed: surface density of alveolar septa, volume density of air spaces distal to the terminal bronchioles, and volume density of the tissue. The first two would quantitatively reflect changes in air space volume or surface area as is seen for example in emphysema; the latter would reflect changes in tissue volume such as would be seen in fibrotic lung disease. No significant differences were noted between the groups.

Histological assessment of the inflated fixed lungs from groups of at least 10 animals were performed at 3,6 and 12 months. An examination of control lungs at all three time periods showed no evidence of fibrotic or neoplastic disease. In some control animals there was a mild perivascular mantle of lymphocytes; however, there was no evidence of any overt inflammatory process. In particular no lesions involving the respiratory bronchioles were seen.

Sections from animals exposed to coal dust, diesel exhaust, or to combined diesel exhaust and coal dust showed similar pathological changes. These changes consisted of collections of macrophages containing black pigmented particles scattered throughout the lungs. The majority were seen within alveoli; lesser numbers were present in the connective tissues of the bronchopulmonary rays and within the bronchial lymphoid tissues. Collections of pigmented macrophages were also seen in alveoli adjacent to some respiratory bronchioles. The lining epithelia of these alveoli showed mild cuboidal metaplasia. At three months there was no evidence of fibrosis, emphysema, or goblet cell metaplasia of the bronchiolar epithelium.

At 6 and 12 months the collections of pigmented macrophages in the alveoli adjacent to the respiratory bronchioles were larger and resembled coal macules (fig 1-3). There was no evidence of focal emphysema. Some of the macrophages appeared to be incorporated within the walls of the respiratory bronchioles, and there were increased numbers of fibroblasts in relation to these lesions. However special stains failed to demonstrate increased collagen production. The patho- logical changes were of equal severity in all three exposed groups.

\section{Discussion}

These comments will be brief as the results presented are preliminary, and much of the data has yet to be analyzed. Thus significant changes may be observed at later time periods. The demonstration of mutagenic compounds in extracts of the diesel exhaust was not surprising in view of several published reports documenting mutagenic and carcinogenic compounds in diesel exhaust $(11,14)$. Mutagenic compounds or metabolites were not found however in the urine of exposed animals, nor were sister chromatid exchanges detected in peripheral lymphocytes. These findings indicate that the mutagenic compounds present in diesel exhaust are either present in very low concentrations or are not biologically available, possibly as a result of binding to carbon particles (4).

Although diesel exhaust appears to contain compounds requiring metabolism for mutagenic activity, we observed no change in cytochrome $\mathrm{P} 450$ activity in the lung microsomes of rats exposed for three months. The lack of change may be due to (i) an insensitivity of the enzyme complex to the conditions of the exposure, (ii) a temporal effect which is not evident at three months, or (iii) a sample size too small to detect small changes in enzyme levels.

Histopathological assessment showed that dust was being deposited in the alveoli where it appeared to accumulate within alveolar macrophages. No evidence of macrophage cytotoxicity was observed, though a definitive statement on this will have to await results of ongoing electron microscopic and macrophage function studies. Accumulations of pigmented macrophages within alveoli adjacent to respiratory bronchioles were observed in all groups as early as three months after initial exposure. These accumulations increased up to 12 months, at which time they were being incorporated into the walls of the respiratory bronchioles. In many respects the lesions resembled the coal macules seen in simple coal worker's pneumoconiosis; however there was no 


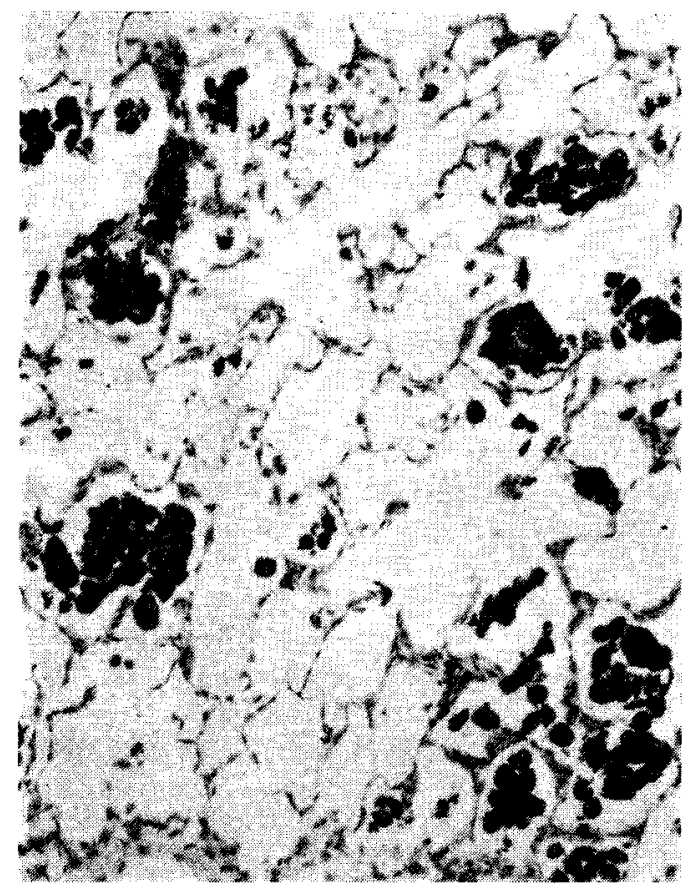

Fig. 1. Section from the lung of a rat exposed to diesel exhaust for six months. Collections of black pigmented macrophages are seen within alveoli adjacent to respiratory bronchioles. (Hematoxylin and Eosin, $32 \times$ )

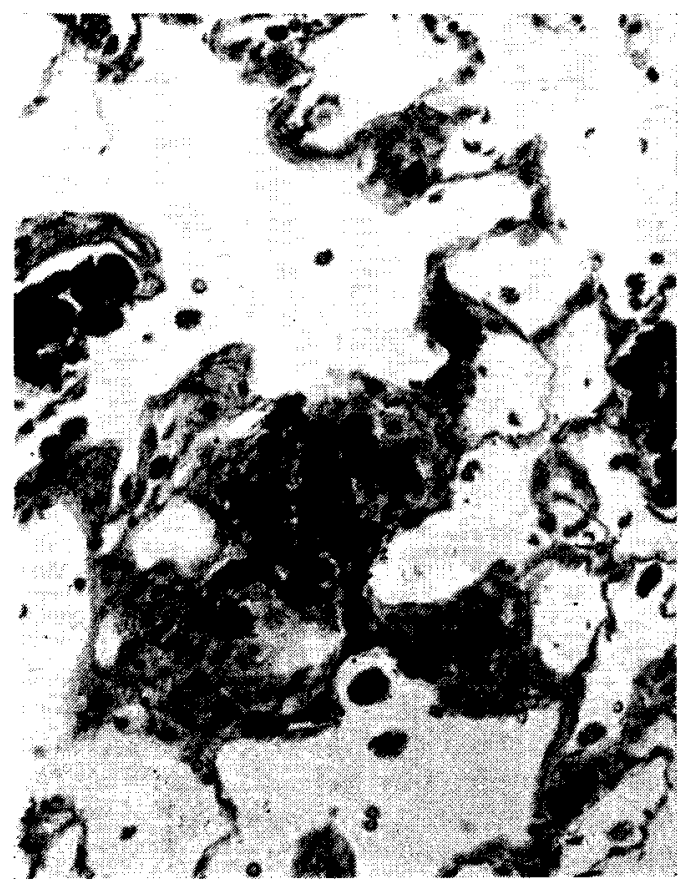

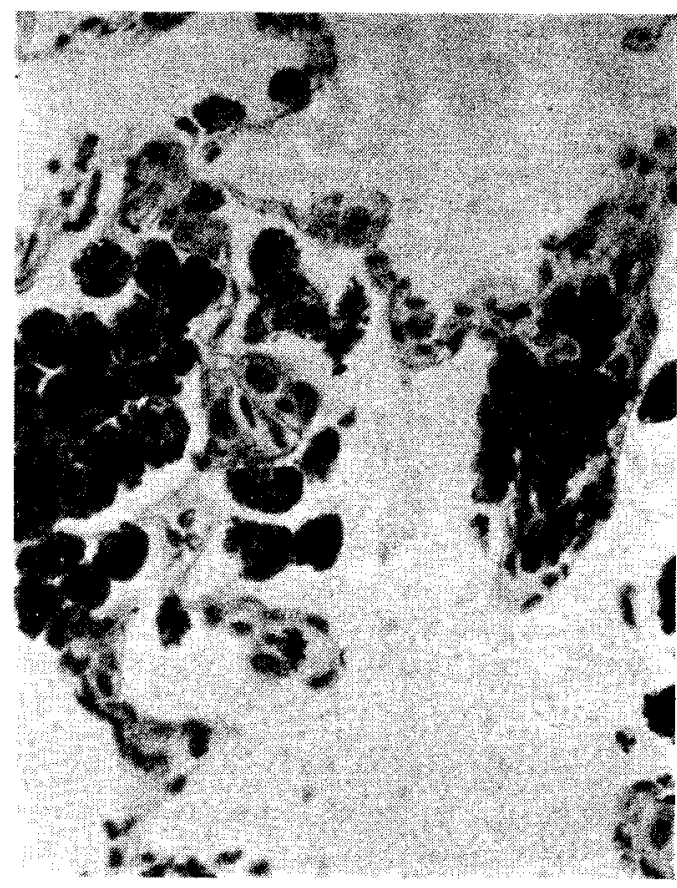

Fig 2. Section from the lung of a rat exposed to coal dust for six months. Macrophages containing dust are seen filling alveoli and in the wall of a respiratory bronchiole (Hematoxylin and Eosin, $50 \times$ )

Fig 3. Section from the lung of a rat exposed to combined diesel exhaust and coal dust for six months. Pigmented macrophages are seen within alveoli and in the wall of a respiratory bronchiole. There is cubodial metaplasia for the alveolar epithelium adjacent to the dust. (Hematoxylin and Eosin, $50 \times$ ) 
evidence for the development of the focal emphysema often associated with the macule (13). This finding may reflect the low dose levels used in this study as Karagianes et al (12) have reported that rats exposed to concentrations of diesel exhaust or coal dust particulate ranging from $6-15 \mathrm{mg} / \mathrm{m}^{3}$ developed fibrotic macular lesions with focal emphysema.

The relatively trivial lesions noted histologically in the lungs at 12 months did not appear to produce any physiological impairment. Tests reflecting changes in elastic lung properties and central and peripheral airways resistance showed no differences between control and exposed animals at 12 months. Morphometric analysis of carefully controlled tissue sections from the same animals also failed to demonstrate any subtle changes in alveolar size or in the volume of interstitial tissue. These tests will be repeated at 24 months.

In conclusion very few pathological changes of significance have been demonstrated in animals exposed to low concentrations of coal dust, diesel exhaust, or combinations of the two for up to 12 months. Ongoing studies on macrophage function, immune function, and tumor prevalence have yet to be analyzed, and studies on infectivity and clearance are in progress. The results of these studies may materially alter the conclusions to date.

\section{Acknowledgments}

The authors thank $\mathrm{Mr} \mathrm{KJ}$ Manion and Ms M Gamble for their technical assistance, Dr M Peterson for the statistical analyses, $\mathrm{S}$ Shores and $\mathrm{K}$ Kennedy for their secretarial assistance, G Taylor for his early participation in the project planning, and $J$ Stewart for the mutagenicity testings. Ms J Mull kindly performed the hematology profiles. Mr $\mathrm{K}$ Cambell was on-site project coordinator and responsible for the aerometry determinations. B Wheeler provided valuable environmental data on underground dieselized coal mines.

\section{References}

1. Ames RG, Attfield MD, Hankinson JL, Hearl FJ, Reger RB. Acute respiratory effects of exposure to diesel emissions in coal miners. Am rev respir dis 125 (1982) $39-42$.

2. Ames BN, McCann J, Yamasaki E. Methods for detecting carcinogens and mutagens with the Salmonella/mammalianmicrosome mutagenicity test. Mutat res 31 (1975) $347-364$.

3. Boyd RL, Fisher MJ, Jaeger MJ. Noninvasive lung function tests in rats with progressive papain induced emphysema. Resp physiol 40 (1980) 181-190.

4. Creasia DA, Poggenburg JK, Nettesheim P Jr. Elution of benzo(a)pyrene from carbon particles in the respiratory tract in mice. J toxicol environ health 1 (1976) 967-975.

5. Danner-Rabovsky J, Groseclose RD. Stability of rat lung and liver microsomal P450 activites to storage: Purified microsomal fraction, post mitochondrial fraction and whole tissue. J toxicol environ health (in press).

6. Garner RC. Carcinogen activation and the biological detection of activated metabolites. J soc occup med 29 (1979) 54-60.

7. Greenlee WF, Poland A. An improved assay of 7-ethoxycoumarin 0-diethylase activity: Induction of hepatic enzyme activity in C57BL/GJ and DBA/2J mice by phenobarbital 3-methylcholanthrene and $2,3,7,8$-tetrachlorodibenzo-p-dioxin. J pharmacol exp ther 205 (1978) 596-605.

8. Heidelberger C. Chemical carcinogenesis. Ann rev biochem 44 (1975) 79-121.

9. Hinners RG, Burkart JK, Malanchuk M, Wagner WD. Facilities for diesel exhaust studies. In: Pepelko WE, ed. Health effects of diesel engine emissions: Proceedings of an international symposium. Environmental Protection Agency, Cincinnati, OH 1980, pp 691-698. (EPA-600/9-80-0756).

10. Hinners RG, Burkart JK, Punte CL. Animal inhalation exposure chambers Arch environ health 14 (1968) 553-559.

11. Huisingh J, Bradow R, Jungers R, Claxton $\mathrm{L}$, Zweidinger R, Tejada S, Bumgarner $\mathrm{J}$, Duffield F, Waters M, Simmon V, Hare C, Rodriguez C, Snow L. Application of shortterm bioassay to the characterization of diesel particle emissions. In: Waters $\mathrm{MD}$, Nesnow S, Huisingh JL, Sandhu SS, Claxton L, ed. Application of short-term bioassays in the fractionation and analysis of complex environmental mixtures. Plenum Press, New York, NY 1978, pp $383-418$.

12. Karagianes MT, Palmer RF, Busch RH. Effects of inhaled diesel emissions and coal dust in rats. Am ind hyg assoc j 42 (1981) 382-391.

13. Kleinerman J, Green F, Laqueur W, Taylor G, Harley R, Pratt P, Wyatt J, Naeye R. Pathology standards for coal workers' pneumoconiosis. Arch pathol lab med 103 (1979) 375-432.

14. Kolin P, Valk HC, Thomas M. Aromatic hydrocarbons: III Presence in the particulate phase of diesel engine exhaust and the carcinogenicity of exhaust ex- 
tracts. Arch ind hyg occup med 11 (1955) 113.

15. Lowry DH, Rosenbrough NJ, Farr AL, Randall RJ. Protein measurements with the Folin Phenol Reagent. J biol chem 193 (1951) 265-275.

16. Pelkonen $O$, Vahakangas $K$. Metabolic activation and inactivation of chemical carcinogens. $J$ toxic environ health 6 (1980) 989-999.

17. Perry P, Wolff S. New Giemsa method for the differential staining of sister chromatids. Nature (London) 251 (1974) 156-158.

18. Philpot RM, Anderson MW, Eling TE. Accumulation and metabolism of chemicals by the lung. In: Bakhle JS, Vane JR, ed.
Metabolic functions of the Iung. Marcel Dekker, New York, NY 1977, pp 123-171.

19. Reger $R$, Hancock J, Hankinson J, Hearl F, Merchant J. Coal miners exposed to diesel exhaust emissions. In: Walton WH, ed. Inhaled particles V. Pergamon Press, Oxford (in press).

20. Weibel ER. Stereological methods. Volume I (Practical methods for biological morphometry). Academic press, New York, NY 1969.

21. Yamasaki E, Ames BN. Concentration of mutagens from urine by absorption with the nonpolar resin XAD-2: Cigarette smokers have mutagenic urine. Froc natl acad sci usa 74 (1977) $3555-3559$. 